\title{
I bassäng med nationen \\ - när simmande kroppar blir gemenskap
}

\section{Af Mathilda ERnberg}

\section{ABSTRACT}

Swimming with the nation - when swimming bodies become community

In this article, national belonging is discussed and demonstrated as a political and historical situated project through an examination of contemporary debates concerning the possibility of gender-segregated opening-hours in Danish bath-houses. Drawing on postcolonial feminist understandings, the article shows how these debates relate to otherness, diversity and national identity. Further, the debates can be seen as part of political and national interests and power-relations, where a (hi)story of progress and development is being used to establish certain hierarchies and feelings of superiority, especially in relation to gender, race, and sexuality. The article finds these interests manifested in, and though, perceptions and constructions of agency and certain bodies, limited space for agency and being.

\section{KEYWORDS}

Nationalism, belonging, gender, sexuality, otherness, equality, feminism 


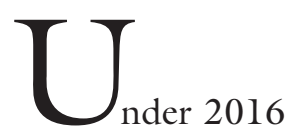

blev ämnet om könsuppdelat tidsrum i danska simhallar (återigen) omdiskuterat i dansk media på bakgrund av Aarhus Byråds beslut som inte längre möjliggör besökstider för enbart flickor/kvinnor i stadens simhallar, med argumentet att offentliga instanser inte inrättar sig efter religiösa dogmer (Johansen 2016).

Bland annat i samband med en ny dansk lag om 'tildækningsforbud', som är gällande från och med augusti 2018 (Justitsministeriet 2018), har logiker och resonemang från simhallsdebatten en fortsatt aktualitet. Diskussioner kring både simhallsdebatten och i relation till förbud av kvinnlig muslimsk påklädnad förhandlar med, och är infiltrerade av, logiker och argument om kvinnlig frigörelse, nationell anpassning och patriarkalt förtyck. Interaktioner mellan dessa ämnen skapar ambivalenser och paradoxer, och har engagerat röster mot könssegregerad simning över en bred vidd av argument och intressen vilket vittnar om en komplexitet som gör sig relevant för en analys av könade gränser i nationsskapande processer. Debatten är också relaterad till kroppars tillgänglighet i det offentliga rummet, som rasifierat och nationellt begränsande.

I den här artikeln fokuserar jag på den ovan nämnda debatten i en analys av nationell tillhörighet där kön och sexualitet spelar en navigerande och disciplinerande roll (Yuval-Davis 2011), vilket vidare studeras i relation till föreställningar om progression och modernitet. Jag förstår dessa diskussioner som en exemplifiering av en tendens där nationalistiska logiker definierar, och använder sig av, kvinnlig frigörelse. Med denna ingång intresserar jag mig för maktpraktiker som opererande med bland annat tid, nationalitet, sexualitet och kön. Tid förstås som ett verktyg enligt neoliberala marknadslogiker; som en föreställning om en kommande progression, och är nödvän- dig att undersöka för att synliggöra vem som möjliggörs och vem som omöjliggörs i samhällspolitiska mål och visioner, med behov av hotbilder för att motivera tilltag som främjar progressionen (Brown 2015).

Könssegregerade simhallar har väckt debatt i fler europeiska länder, däribland Danmarks grannländer Norge och Sverige. Speciellt i Sverige har debatten centrerats vid föräldrar som hindrar sina barn från att delta i könsblandad simundervisning, där argument relaterat till religion och jämställdhet inte fått lika stor fokus, med har också varit representerade (jmf. Mohammad 2015).

Logiker och argument i den danska debatten rymmer en bredd av intressen och utgångspunkter, vilka inte presenteras i sin helhet i min analys. Förespråkare för ett danskt förbud mot könssegregerad simning är således är inte begränsade till röster från nationalistisk organisering. Från en plattform för jämställdhet har till exempel Nina Groes, dåvarande direktör för det danska forsknings- och utvecklingscentret KVINFO, uttalat: "Ligestilling er afgørende for det danske samfund, og derfor skal vi værne om, at børn på tværs af køn kan svømme sammen" (Dereyer 2016a). Även forskare i Statsvetenskap, Jens Peder Frølund, argumenterar för ett förbud med utgångspunkt $i$ att ordningen matar stigmatisering genom specialbehandling (Gottschalck 2016), och debattör och sociolog Javeh Tavakoli såväl som författare och debattör Geeti Amiri har uttalat att ordningen främjar social kontroll och försvårar invandrarflickors frigörelse (Sæhl 2017).

Det diskuterade förbudet har även mött motstånd. Bland annat från delar av vänsterorienterade partier och från aktivistgruppen “Kvindesvømningens Venner ved Gellerupsbadet", tillsammans med en rad antirasistiska organiseringar. Som exemplifierande presentation av andra röster som visat motstånd, har bland annat förman för 
DGI-byen i Köpenhamn, Søren Møller, fokuserat på ett positivt ökat deltagande i simundervisning (Ritzau 2017). Från andra håll har förbudet sammankopplats med en islamofobisk tendens (Ventegodt Liisberg 2016) och kritiserats utifrån perspektiv på religion som en privat angelägenhet (Birk 2016).

Med intresse i nationalism och nationsskapande i relation till kön som interagerande med sexualitet i den ovan nämnda debatten bygger mina resonemang på teoretiska perspektiv på nationsskapande i könade intersektioner (Yuval-Davis 2011; Scott 2011; Yong 2005). Artikelns analysdel är indelad i olika teman identifierade utifrån debatter i Danmark om könssegregerad simning utifrån tre överskrifter; 1) Kön och sexualitet som nationell tillhörighet, 2) Könsbaserat förtryck - inte $i$ denna bassäng! 3) Föreställningar om progression - en könad historia, samt ett avslutande stycke där ambitionen är att sammankoppla de tre avsnitten under underskriften Jämställdhet som omöjliggör jämlikhet. På grund av ämnenas närhet och avhängighet av varandra är texterna under de olika överskrifterna dock inte tematiskt avgränsade, utan överlappas.

\section{METODOLOGISKA UTGÅNGSPUNKTER OCH URVAL}

Min utgångspunkt i arbete med att analysera texter är texten som producerande och reproducerande av sociala och materiella förhållanden. Relationen till text är därmed med hänvisning till en teoretisk förståelse av kunskapsproduktion och makt genom språkliga praktiker; mina teoretiska utgångspunkter ger mig möjligheter, riktlinjer och kunskap i mitt material. Här lutar jag mig på Mieke Bals förståelse av koncept som bärande på meningar, vilka berättar om antaganden och etablerade 'sanningar' som legitimerar argument, logiker och relationer (Bal 2001, 16). Enligt denna linje behandlas texterna genom att undersöka vad nationell tillhörighet (exkludering och inkludering) interagerar med för att ges mening, med fokus på nationalitet $\mathrm{i}$ intersektioner med kön och sexualitet. De allianser, outsagda gemenskaper och förgivet tagna verkligheter texterna presenterar är därmed interagerande med de relationer och tillhörigheter som är analysens studieobjekt. I mitt undersökande är det främst framställningar av föreställda problem i dessa relationer och tillhörigheter (Bacci 2009, $25)$ som jag försöker följa.

Urvalet av texter är ett resultat av sökningar på "kønsopdelt svømning”, där jag valt ut texter från större etablerade danska nyhetsportaler där ämnet debatterats. I analysen presenteras urklipp från cirka tio texter som ska läsas som ett begränsat urval vilket representerar något i den gällande debatten, men inte som en heltäckande presentation. Andra val av texter och andra analytiska utgångspunkter hade kunnat identifiera andra sanningar och perspektiv än de jag finner i min analys.

\section{ForSKNING OM NATIONALISM, RASISM OCH KÖN I NORDEN}

Intresset för rasifierande och nationalistiska markeringar i norden har engagerat en rad feministiska forskare från en bredd av vetenskapliga discipliner (jmf. Andreassen 2015; Bang Svendsen 2014; Hervik 2015; Keskinen 2013; Palmberg 2009) vilka bidrar med en mångfald av relevanta och intressanta perspektiv på nationsskapande processer med kopplingar till mitt undersökningsområde. I antologin Complying with colonialism. Gender, race and ethnicity in the Nordic region (2009) presenterar Suvi Keskinen et al. ett solitt fundament av feministiska bidrag som demonstrerar hur nordiska länder bär på narrativ som frånskrivs en historia av kolonialisering, vilket resulterat i en frånvaro av erkännande eller uppgör med detsamma. Genom dessa bidrag presenteras bland annat hur en nationell självbild i nordiska länder istället är be- 
roende av 'den andra', både som utvecklingsobjekt och som hot, för att upprätthålla nationell överlägsenhet (Eide och Simonsen 2008).

Hur dessa tendenser även gör sig gällande i den nationella kontexten för min analys, har bland andra Rikke Andreassen (2013) och Helene Pristed Nielsen (2012) belyst med forskning om bland annat danska minoritetskvinnors syn på jämställdhet, kön och sexualitet. I studien identifierar Nielsen hur minoritetskvinnor framställs som bakåtsträvande, i linje med mitt antagande om könade och nationella markörer som relaterat till progression. Dessa tendenser samverkar med politiska förskjutningar i integrationsinsatser, från nationell till lokal nivå, med ökat individualiserat bemötande av samhällets individer (Scholten et al. 2017), där integration blir egenansvar; att bli integrerad och att skapa sig själv som en del av den nationella gemenskapen. Tendenser som också relaterar till debatter om muslimsk klädsel, som menas försvåra individens anställningsbarhet och som därför diskuterats som en laglig omöjlighet (Andreassen 2013). Logikerna motiverar utgångspunkter där inkludering värderas utifrån samhällsnytta, vilket resulterar i krav på assimilering som nödvändigt för likabehandling (Holck och Muhr 2017; Scott 2011). En nationell välfärdssjälvförståelse där kön och ras fungerar som fördelande och kategoriserande faktorer för 'innanför' och 'utanför' (Nygren et al. 2015) är därför närvarande och fundamental i debatten för min analys, som opererar med logiker i relation till ansvar och skyldighet, där kvinnors möjlighet för att delta $\mathrm{i}$ könssegregerat rum i simhallar kan antas beröra individens egenansvar för att bli en integrerad och anpassad medborgare.

Intersektionella studier i Danmark har utifrån ett brett forskningsfält, från bland annat kulturstudier, litteraturstudier och studier med avstamp i pedagogik och utbildningsvetenskap, påpekat tillhörighet som skapat i rasifierande och andrafierande processer (jmf. Bissenbakker och Myong 2016; Koefod 2005; Søndergaard 2004).

Argument i diskussioner kring könssegregerade i simhallar genererar i logiker om giltiga jämställdhetsargument samt kroppen och dess tillgänglighet i offentliga rum, och är relevanta att studera som förhandlande och inkräktande på frihetsideal, i dialog med vad som ofta definieras som neoliberala normer för individualism och ansvar (Fahlgren et al. 2011). Debatten är således en demonstration av hur politiska och samhällsmässiga tendenser och (motstridiga) logiker avspeglas i komplexa fenomen i görande och upprätthållande av nationens gränser.

\section{TEORETISKA PERSPEKTIV PÅ NATIONEN}

Min utgångspunkt för tolkning av debatten är nationen som en konstruktion av bland annat kön och sexualitet, där föreställningar och logiker baserade på tid- och utvecklingsförståelser skapar en enad, överlägsen och materiellt avgränsad helhet. Nationella gränser upprätthålls i interaktion med fysiska, såväl som historiskt och socialt betingade gränser, markerade med kön som fundament för social organisering, och är därmed avgörande för hur makt internaliseras och fungerar via disciplinering som inramar (o)möjligheter för nationell tillhörighet (Mulinari och Nergaard 2010). Denna tillhörighet (re)produceras genom normaliseringsprocesser som är avhängiga av motsatsens närvaro; ett utanför normalen som markerar och ger gränser åt det normala (de los Reyes 2005; Martinsson 2005). Det vill säga att 'vi:et' som nation inte har möjlighet att existera utan närvaron av ett exkluderat 'dem' som manifesterar (konstruerat) disparata grupperingar (Sager 2011). Dessa processer är nödvändiga att uppmärksamma och analysera som processer där nationen och det nationellt tillhörande innebär tillgångar, privilegier och rättigheter (Nygren et al. 2015); en produktion och reproduktion av nationens överlägsenhet (van Dijk 
1993, 20). Tid, som progression eller regression, samverkar häri som konceptualisering och tilldelning, där bestämda kroppar och praktiker blir representationer för utveckling och framgång (de los Reyes 2006). Den feministiska kulturvetaren Sara Ahmed (2011) bidrar med betydande perspektiv på nationella gemenskaper och homogen lojalitet som implementerat och reproducerat via 'löften' om känslomässiga koncept som frihet och harmoni. Dessa resonemang kopplar Ahmed till materiella gränser, delvis konstruerade via kroppsliga representationer som (o)möjliga reproduktioner av nationen (ibid., 180 ff.). Politik och insatser som skapar bestämda grupper som nödvändiga att begränsa och disciplinera konstruerar därmed föreställningar där dessa grupper framstår som (och blir) rasifierade (Weheliye 2014) och underlägsna, vilket ger insatserna mening och legitimitet. En utgångspunkt $\mathrm{i}$ min analys är att integration som koncept utgår från denna tanke och praktik, då något framställs som att vara i behov av att integreras $i$ något annat; en producerad och reproducerad uppdelning av människors olikhet och position.

\section{BEGREPPET 'LIGESTILLING'}

Även om jag i mitt möte med empirin inte explicit fokuserar på begreppet ligestilling (jämställdhet), så relaterar de problem, logiker och argument som rör sig i debatten om könssegregerade tider i simhallar, till konceptet. Begreppet förtjänar därför några raders uppmärksamhet innan jag inleder en analys av debatten. I linje med Fahlgren et al. (2011) analyserar jag jämställdhet som en plattform varpå normalisering fungerar. Av det norska begreppet för jämställdhet, likestilling, har forskarna Kristin Spikler och Merete Lie banat vägen för en relevant diskussion. De påpekar att begreppet är beroende av något likt som kan värderas utifrån statusen som just lika. Innebörden refererar därmed till en homogenitet för att möjliggöra lika behandling. Debatten om köns- segregerad simning kommer runt många aspekter och tolkningar av olikhet i förhållande till kön, främlingskap och olikhet som över- eller underordning.

Begreppen ligestilling och jämställdhet kan förstås i relation till bestämda utgångspunkter och föreställningar om olikhet betingat av bland annat kön och sexualitet (Bondestam 2009) där begreppen antar en bestämd olikhet möjlig att reglera med en önskad intervention. När denna reglering appliceras i en etablerat könad samhällsorganisering, riskerar konceptet att begränsas till att fungera som assimilering till rådande normer. Det vill säga att konceptet saknar ett maktperspektiv. Denna utgångspunkt är nödvändig för att förstå könssegregerad simning som problematiserat.

\section{DEBATTER OM ÖPPETIDER FÖR SIMNING I DANSKA SIMHALLAR: KÖN OCH SEXUALITET SOM NATIONELL TILLHÖRIGHET}

"Så synes jeg nærmere, at de skal finde nogle andre tiltag, hvor de kan få pigerne integreret. Det er jo ikke vejen frem at styrke parallelsamfund og understrege, at islamismen blomstrer frit i Danmark med sharia-lignende forhold, hvor man adskiller drenge og piger fra en helt ung alder (...). Hvis man făr ophold i Danmark, fordi man har behov for at fă beskyttelse, så synes jeg som minimum, at man skal efterleve de normer og den kultur, vi har i Danmark" (Dalgaard 2016).

Citatet ovan av Marcus Knuth, Venstres Integrationsordfører, lyfter fram vikten av att "pigerne" blir integrerade genom en logik som skapar sammanhang mellan en bestämd könsförståelse/ordning ("de normer og den kultur") och nationell inkludering ("vi har i Danmark"). Tendensen känns igen från sociologen Joan Scotts analyser av ett västerländskt jämställdhetsprojekt i en fransk kontext, där debatter och logiker bakom motstånd mot kvinnors bärande av 
muslimsk huvudduk undersöks. Scott synliggör hur exponering av könade kroppar som olika, fungerar som en premiss för att skapa jämställdhet mellan könen (Scott 2010); inkludering i nationens jämställdhetsprojekt kräver assimilering till nationens förståelse och organisering enligt två kön, och dess sexuella relation emellan. Citatet ovan representerar en logik baserad på en könsförståelse där pojkar och flickor exponeras för varandras kroppar för att synliggöra "de normer og den kultur, vi har i Danmark". Olikhet och innebörden av olikhet definieras således av positionen i makt och majoritet (Prashad 2000). I Knuths citat är olikheten och existensen av två kön etablerat, som tydligt markerar "drenge og piger" som två motsatta kategorier. Men den (kroppsliga) olikhet som här definieras, tillåtas inte som osynlig för sin 'motsats', om den ska anses som jämställd och nationellt integrerad. Närvaron av könens olikhet blir en premiss för det nationellt tillhörande; assimilation blir möjlig likabehandling (Holck och Muhr 2017). I samma linje fortsätter Jacob Mark från Socialistisk Folkeparti:

“[det] er jo et udtryk for, at pigerne kommer fra nogle familier, hvor der ikke er demokratisk og rigtigt ligestillingssyn på kvinder (...) det er jo et udtryk for, at der er nogle patriarkalske normer og familier, der ikke har det syn på kvinder, som jeg mener, at man bør have, når man bor i Danmark" (Dalgaard 2016).

Förutom att denna logik hänvisar till patriarkala normer som icke- existerande i Danmark (något jag vänder tillbaka till under kommande avsnitt), så manifesteras här en syn på kvinnor som "man bør have, når man bor i Danmark". Det icke-främmande/rasifierade blir tilldelat en nationell objektivitet och 'sanning' (Andreassen och Myong 2017, 102).

Sociologen Nira Yuval-Davis (2011) begriper kön och sexualitet som organiserat på bestämda vis i olika kontexter av (politisk) gemenskap i relation till gällande politiska projekt och maktordningar. Det innebär att en homogen förståelse av kön blir viktig för det nationellt politiska projektet. Denna tendens avspeglas i Martin Henriksens (Dansk Folkeparti) bemötande av könssegregerad simundervisning:

"Skal vi acceptera, at det er deres normer, der er afgørende for, hvordan vi indretter samfundet, eller skal vi arbejde på, at det bliver vores normer? (...) Det er meget muligt , at de bliver gode til at svømme, men de bliver ikke integreret af det her. De bliver fastholdt $\mathrm{i}$ de kønsroller, der er” (Dalgaard 2016).

Inte bara "vores" (nationens) (köns)normer är under hot av “deres” (köns)normer, utan hela samhället är hotat enligt detta resonemang. Enbart en integrering (assimilering) till "vores" könsroller kan dels upprätthålla det önskade samhället, dels lösgöra "dem" (kvinnorna) från positionen som "fastholdt i de kønsroller der er". Integrationsminister Inger Støjbjerg från regeringspartiet Venstre uttalar sig i samma linje:

"Det kan godt være, at de her piger lærer at svømme, men de bliver jo ikke integreret. Og det er jo det det hele handler om. (...) man kan ikke begå sig i Danmark, hvis man ikke kender til danskere og har făet danske værdier og normer ind under huden" (Redder 2016).

Här explicerar Støjbjerg att debatten inte handlar om huruvida flickor och pojkar ska behandlas lika, utan om att människor som kommer till Danmark ska ha "danske værdier og normer ind under huden" och att dessa normer handlar om bestämda strukturer och förståelser i relation till kön och sexualitet. En relation mellan känslomässig och politisk, nationell tillhörighet ges därmed uttryck (Yuval-Davis 2011). Med Ahmeds teoretisering kan uttrycket förstås som en manifestation av den nationellt markerade kroppens reproduktion av natio- 
nell 'harmoni', i motsats till en representation av det som 'stör' nationens enhet (jmf. också Danbolt 2017). Kön som dolda för varandra i könsseparata rum uppträder i dessa citat i resonemang där en bestämd organisering enligt kön och sexualitet krävs för att vara och behaga som nationellt objekt. Kön ges därmed uttryck åt att vara laddat med mer än föreställningen om två motsatta positioner via framskrivningar av genom vilka (giltiga) begär dessa positioner förväntas relatera till varandra (Butler 2001), det vill säga konstruktionen av en 'riktig' (hetero)sexualitet.

\section{KÖNSBASERAT FÖRTYCK - INTE I DENNA BASSÄNG!}

Ann Towns har i en svensk kontext studerat hur konstruktioner av negativa 'främmande' kulturer relaterar till argument för jämställdhet (Towns 2002, 168). I denna forskning betonas hur jämställdhet används för att skapa en distinktion mellan vad som föreställs som svenskt (jämställt) i motsättning till patriarkala strukturer som tilldelas en kultur. I samma linje har Andreassen skrivit om dansk medias fixering vid muslimska patriarkala strukturer som ett sätt att framställa danska kvinnor som i motsats; frigjorda och jämställda (Andreassen 2013). Det oönskade 'bär' därmed på något som blir destruktivt för den nationella gemenskapen. För att ge konturer åt, och skapa avstånd till, en patriarkal struktur, visar dessa resonemang hur kvinnan blir objekt för det förtryckta och ofria, möjligt att bli fritt genom den nationella jämställdheten.

"Det kommer an på, hvordan integration defineres. Hvis succeskriteriet er, at pigerne lærer at svømme, så er det succesfuldt, men det er ikke integration. Og hvis man mener, at kønnene bør være fuldstændigt ligestillede, og at piger ikke må begrænses af deres køn, så er det heller ikke integration" (Dreyer 2016b).
Citatet, från debattör Geeti Amiri, ska läsas som ett svar på frågan "Er det succesfuld integration?" i förbindelse med könssegregerad simhall, och är intressant i förhållande till Towns och Anderassens resonemang. Det påtalande i detta citat är aspekter på könad begränsning, något som också uttrycker paradoxer och komplexitet i förhållande till 'frihet' i debatten. Att inte begränsas på grund av sitt kön är något som i detta resonemang är möjligt i den verklighet som erbjuds när "pigerne" $\ddot{a} r$ integrerade. Att delta på premisser då deltagarna antas integrerade, alltså danska, antas som premisser fria från begränsningar, som här uppstår genom att frånta friheten att välja könssegregerad simning.

Socialdemokratiets partiledare Mette Frederiksen uttalar i debatten:

"Vi er frie individer. Og hverken børn, kvinder eller badning skal underlægges et forskruet syn på køn. Lad os skabe rigtig integration. På lige vilkår” (Ritzau 2016).

Argumentationen antar 'sanningen' om att i Danmark råder en 'korrekt' (till skillnad från "forskruet" (skev)) syn på kön, som möjliggör "frie individer" genom "rigtig integration". Debatten om könssegregerat rum blir därmed en debatt vilken också handlar om skolning i en 'riktig' syn på kön, som inkluderar dess olikhet och (sexuella) relation till varandra. Genom denna skolning blir bestämda kroppar ett hot mot en lyckad integration och framgångsrik jämställdhet.

Med fokus på vilka objekt som representerar detta hot intresserar sig Aleksandra Åhlund för hur invandrade blir ett problem genom föreställningar om jämställdhet (2005). Konceptet jämställdhet fungerar därför inte enbart som ett sätt att skapa den invandrade som olik och främmande i integrationsprocesser, utan också som ett sätt att osynliggöra de sociala och orättvisa strukturer som existerar i den kontext som åtar sig viljan att integrera. Konceptet lige- 
stilling och en 'korrekt' syn på kvinnor och kön, frånskrivs systematiskt det främmande (muslimska) och framställer därmed, det 'riktiga' (fria, obegränsat av könade strukturer) som lika med danskt (Andreassen 2013). Detta har påträffats i argument både för och emot könssegregerad simning. Olikheten som reproduceras i utpekandet av olika kulturer, skapar förståelse och legitimitet för olik behandling, begränsad frihet och orättvis fördelning, makt och status, som sedan avspeglas i samhällsordningar och strukturer. Föreställningar som också legitimerar frånvaron av de kvinnor det talas om, som objekt för förtryck, i dessa diskussioner och debatter (Nielsen 2012).

\section{FÖRESTÄLLNINGAR OM PROGRESSION - EN KÖNAD HISTORIA}

När könade strukturer och brist på jämställdhet används för att peka ut det icke tillhörande och samtidigt används för att dra gränser som framhäver nationell överlägsenhet, sker det genom föreställningar om nationen som mer utvecklad (Burcar Alm 2012); det främmande används som kontrast till en överordnad nation. Utveckling som process och status relaterar därmed till, och tar definitionsmakt över, en linjär tidsförståelse.

"Jeg ville angribe problemet et helt andet sted. Vi skal gå til de her forældre via vores integrationspolitik og forklare dem, at her kan de ikke få opfyldt særkrav. De skal sende deres piger til idræt og andre aktiviteter som alle andre danskere. Hver gang, vi efterkommer alle de her krav, nedbryder vi det samfund, vi ellers har kæmpet for” (Dreyer 2016c).

I citatet formulerar Carl Christian Ebbesen från Dansk Folkeparti dansk politik som ett överlägset koncept, med syftet att "forklara" för "dem" vad som gäller; en manifestation av rätten till disciplinering och makt. Citatet refererar också till en tidsmässig aspekt och förståelse av utveckling, med re- ferensen till en uppnådd progression där "dem" beskrivs som hotande för det samhälle som "vi ellers har kæmpet for".

Förståelser av progression och etablerade tolkningar av jämställdhet och könens lika värde inom nationen, används också som argument för den könsuppdelade simundervisningen. Michael Gatten från Radikal Vestre, medlem av den instans som har beviljat ekonomiskt stöd till projekt med könssegregerad simhall, argumenterar enligt samma logik: "Den her indsats virker, den skaber integration, piger kommer ud og i foreningslivet. De kommer ud af hænderne på de forældre, der er forvirrede i forhold til demokratiske værdier" (Ejsning 2016). Syftet med projektet formuleras som en integrationsinsats med föremålet att barn (piger) ska befrias från "forvirrede" föräldrar i förhållande till danska "demokratiske" värderingar. Bestämda sätt att organisera och förstå könade (och den sexualiserade relation som könen förstås genom) strukturer fungerar i dessa argument som faktorer och reproduktioner, vilka förklarar progression och utveckling som tillhörande en bestämd (nationell) gemenskap (de los Reyes 2005, 162). Därför kan könssegregerat rum som önskas av simhallsbrukare med andra grunder än de som tilldelas de religiösa (icke-danska) framställas som ett oproblematiskt positivt erbjudande, vilket framkommer i Socialdemokraten Peder Udengaards uttalande:

"Som byråd skal og kan vi ikke acceptere at kvinder af religiøse årsager kun må benytte offentlige svømmebade, hvis der ikke er mænd til stede. Det er grundlæggende i modstrid med de værdier, som vores demokrati er bygget op omkring. Man kan ikke være andet end modstander af kvindeundertrykkelse." (...) Partiet kan dog ikke støtte Venstres oprindelige oplæg. Problemet er ifølge Peder Udengaard, at Venstres forslag ikke tager højde for de frivillige foreninger, som i dag tilbyder svømning af ikke-religiøse årsager (Johansen 2016). 
De icke-religiösa orsakerna frånskrivs som möjliga resultat av en kvinnoförtryckande kultur, då en sådan kultur är icke-existerande i den nationella självförståelsen och blir istället privata och ointressanta att ifrågasätta. Resonemanget faller i linje med tidigare forskning om patriarkala strukturer som 'främmande' (Andreassen 2013; Åhlund 2005; Towns 2002; Nielsen 2012), där könat och sexualiserat förtryck inom nationen får personliga och individuella, $\mathrm{i}$ motsats till kulturella, förklaringar.

Religiösa (muslimska) orsaker till att delta i könssegregerad simning blir därmed en symbol för något bakåtsträvande och reaktionärt, i kontrast till en upplyst och 'modern' kvinnosyn.

Lars Aslan från Socialdemokratariet uttalar i en förlängning av argument om att muslimska kvinnor självklart inte kan begära en könsuppdelad arbetsmarknad:

“Og derfor er kønsopdelte svømmehaller selvfølgelig heller ikke løsningen på at få muslimske kvinder til at svømme. Løsningen er, at vi som samfund står fast på ligestilling og de resultater, vi har opnået på det område, takket være en masse modige kvinders utrættelige kamp for lige rettigheder" (Rasmussen 2016).

Logiken bygger på en given absurditet i föreställningen om att muslimer inte skulle anpassa sig till arbetsmarknaden för att $b l i$ jämnvärdiga (jmf. Holck och Muhr 2017). Resonemang från tidigare forskning om kvinnans handlingsutrymme, som begränsat och disciplinerat när hon blir en nationell symbol (Eduards 2007; Siim 2000) och skapad som den 'Andra' (Mohanty 1984) känns här igen. Kvinnor som kämpat och uppnått en viss nivå av jämställdhet $\mathrm{i}$ Danmark förtjünar i Aslans resonemang att skonas från den 'Andra' kvinnan, som på grund av sin förtyckta position bromsar "på det område". Aslans 'lösning' refererar till ett problem som inte handlar om rätten till simning, men om kvinnokamp, där den muslimska kvinnan som viljelös bromskloss och offer för en patriarkal struktur representerar en bakåtsträvan som Danmark ska skydda alla kvinnor från, vilken får karaktär i Aslans fortsättning:

“Og jeg kommer ikke til at give mig så meget som bare én centimeter i forhold til de reaktionære islamister, som udelukkende er interesseret $i$ at modarbejde det danske samfund og kvinders rettigheder" (Rasmussen 2016).

Ytterligare en viktig aspekt i citaten under detta avsnitt ligger i samma linje som Andreassens resonemang kring debatter om kvinnors muslimska beklädning i Danmark, som påpekar tendensen där danska män påtar sig rollen som 'räddare' av den rasifierade kvinnliga kroppen (Andreassen 2013, 224). Paradoxalt visar Andreassens analys även ett behov av exponering och tillgänglighet till samma kropp (ibid., 220), ett perspektiv från vilket denna analys också kan tolkas och som understryker logikernas normer och 'sanningar' om sexualitet. Argument för kvinnans tillgängliga kropp (och sexualitet) blir följaktligen en del av att ingå i en nationell gemenskap, där en ensartad föreställning om njutning och lust blir väsentlig (Danbolt 2017).

I detta avsnitt har kopplingar till kön och sexualitet i nationsskapande processer i relation till tid diskuterats, vilka synliggör könade markeringar som, inte bara förankrat men också skapande av en linjär tidsförståelse. Bestämda rasifierade och könade kroppar hänvisas till bestämda tider och platser i processer som legitimerar olikhet och ojämlikhet genom förståelser av utveckling och progression (de los Reyes 2005, 64-65). Diskurser om vad progression är och vad det innebär sammankopplas med vem som är möjlig att delta i, och främja, progression. Att hänvisa en bestämd kropp som hinder för jämställdhetsutveckling eller kvinnlig 'frigörelse', ett uttryck som hänvisar till en linjär utveckling med resultat i ett 'klimax', blir därmed ett utryck för hur kön 
skapar tid, och hur definitionsmakt över tid som bärare av progression, fungerar hierarkiserande.

\section{JÄMSTÄLLDHET SOM OMÖJLIGGÖR JÄMLIKHET}

Under överskriften: “Debat: Er kønsopdelt svømning kvindefrigørende eller undertrykkende?" har Danmarks Radio (Sæhl 2017) frågat fyra 'kvindelige debatører' om vad de anser i ämnet. Åsikter, perspektiv och argument skiljer sig mellan debattörerna. Gemensamt för utgångspunkterna är att de i DR:s kommunikation handlar om det könssegregerade rum som 'godt eller skidt', 'kvindefrigørende eller undertrykkende' och, som jag enligt min analys också menar att det handlar om; progression eller regression. Detta på trots av att debattörerna nyanserar och har olika ingångar till vad könssegregerad simundervisning berör. De är dock eniga om att könssegregerad simundervisning och annan idrott är något positivt i relation till kvinnors eget val och självbestämmande över egen kropp, när den inte är religiöst (muslimskt) färgad. Den danska kulturen blir således föreställd som opåverkad av religion, strukturer eller kultur i förhållande till kön. Den blir istället konstruerad som 'fri' och där kvinnors val är betingade av agens och självbestämmande, på bekostnad av att andra kvinnor framställs som hämmade och begränsade till att handla och organiseras enligt religion.

Dessa uttryck för frihet och (o)begränsningar beskriver Scott som en del av det föreställt sekulariserade samhället, med rådande agens och frihet att välja (Scott 2009, 12). I Scotts undersökning av kvinnors bärande av muslimsk klädsel blir resultatet att 'västliga' kvinnors val av kläder kan bottna i en diversitet av grunder, men för den muslimska kvinnan som bär huvudduk finns det bara en tolkning av hennes klädsel; att hon är förtryckt. Resonemanget avspeglar upptäckter i min analys; valet att delta i könssegregerad simning tilldelas de (moderna, upplysta) danska kvinnorna, medan muslimska kvinnor (icke-inkluderade som tillhörande det 'danska') enbart kan förstås som tvingade, när de deltar i könssegregerad simning. Den 'Andra' kvinnan som ett subjekt med agens, vetskap eller vilja blir därmed omöjlig, i en process där kön och ras sammanlänkas och understödjer en bestämd verklighetsförståelse (Andreassen och Myong 2017).

När det handlar om barn i de analyserade texterna är könsuppdelad simning antingen en väg till integration genom att skapa kontakt till danska värderingar, eller ett hinder för att integreras i danska jämställdhetsnormer. Då andra praktiker i idrott för barn innebär segregering baserat på kön (omklädning eller könsuppdelad sport) och argumenten för könsblandad simning inte tyder på tendenser som intresserar sig för att arbeta för en könsneutral icke-binär förståelse av kön, blir argument för könsblandad simning en del av en normaliseringsprocess till en binär könsorganisering. Islam blir här ett hinder för visualisering och konkretisering av olikheten mellan två 'naturligt' olika könade kroppar och dess relation till varandra (Scott 2009). En olikhet som understödjer en olik behandling och fördelning av sociala, materiella och politiska resurser (Scott 2010, 146; Eduards 2005; Siim 2000), och som genom att ha frånskrivit sig som kulturellt betingat, blir en naturlig ordning. Praktiken skapar och erbjuder tillhörigheter och gemenskaper där 'oss' och 'dom' blir verklighet, fördelning och legitim ojämlikhet. I den flitigt använda artikeln Under Western Eyes av Chandra Mohanty (1984), påpekas hur feminister som skriver om 'den Andra' kvinnan, som utsatt och förtryckt under patriarkala strukturer, samtidigt positionerar sig själv och sin överordning. I denna representation blir 'den Andra' kvinnan reducerad till en homogen grupp, medans den 'egna' gruppens kvinnor får större handlingsutrymme genom diversitet och agens (Mohanty 1984). 


\section{SLUTORD}

Kvinnokroppen har i genusvetenskaplig forskning synliggjorts som fungerande symbol i nationella förhandlingar och debatter och är därför högst relevant att analysera som begränsad och av-politiserad i nationsskapande processer (jmf. Eduards 2007; Siim 2000). Aspekter på huruvida den diskuterade könssegregeringen önskas eller kan bottna $\mathrm{i}$ och innebära mångfaldiga och komplexa grunder och effekter hos de kvinnor och flickor som anses förtyckta är aspekter som lyser med sin frånvaro. Likt Nielsens analys blir kvinnorna det talas om i integrations- och jämställdhetsdiskussioner i Danmark sällan relevanta (Nielsen 2012) och i linje med Myong och Andreassen (2017) blir denna situerade erfarenhet och kunskap negligerad i processer som könar och rasifierar. En rasifiering som ofta möts med motstånd i en dansk kontext där nationella föreställningar är oförenliga med rasifiering (Myong och Andreassen 2017, 102). Viktigare än att påpeka och motarbeta rasism eller nationalism blir att som enade njuta av nationellt markerade lustar och kroppar (Danbolt 2017, 111). Den neutrala och eftersträvansvärda kroppen är den passerande, den som vistas i könade rum utan att besväras eller vara förtryckt, objektifierad eller utsatt för strukturer som sexualiserar och disciplinerar. Den representationen är definitivt maskulint kodad och definitivt icke-existerande som livs levande, men högst närvarande och verklig i historien om könsblandad, könsbekväm, fri, sund och dansk badning.

\section{LITTERATUR}

- Ahmed, S. 2011. Vithetens Hegemoni. Hägersten: Tankekraft.

- Ahmed, S. 2014. Not in the mood. New formations: a journal of culture/theory/politics. 82, 13-

28. DOI:10.3898/NEWF.82.01.2014

- Andreassen, R. and Myong, L. 2017. Race, gender and researcher positionality analysed through memory work. Nordic Journal of Migration Research. 7(2), 97-104. DOI:10.1515/njmr-20170011

- Andreassen, R. 2016. Human exhibitions: race, gender and sexuality in ethnic displays. Burlington: Routledge.

- Andreassen, R. 2013. Take off that veil and give me access to your body. An analysis of Danish debates about muslim women s head and body covering. In: Schrover, M. and Moloney, D.M. eds. Gender, Migration and Categorisation. Amsterdam: Amsterdan University Press.

- Bang Svendsen, S.H. 2014. Learning racism in the absence of 'race'. The European Journal of Women's Studies. 21(1), 9-24. DOI:

$10.1177 / 1350506813507717$

. Birk, H. 2016. Kronikken: Danmark er et sekulært land - er det ikke? Berlinske. [Online]. [Lokaliserat 5. Dec. 2017]. Tillgänglig på: https://www.b.dk/kronikker/kronikken-danmark-er-et-sekulaert-land-er-det-ikke

- Bondestam, F. 2010. Kunskap som befrielse - en metaanalys av svensk forskning om jümställdhet och skola 1969-2009. Statens Offentliga Utredningar (SOU) 2010:35.

- Brown, W. 2015. Undoing the Demos. Neoliberalism's Stealth Revolution. New York: Zone Books.

- Burcar Alm, V. 2012. Unga mäns brottsberättelser - "svenskar" och "invadrare" som rettoriska resurser. I: Gottzén, L. och Jonsson, R. red. Andra män. Maskulinitet, normskapande och jämställdhet. Malmö: Gleerups, 81-98.

- Butler, J. 2001. Doing justice to someone. Sex reassignment and allegories of transsexuality. GLQ. A Journal of Lesbian and Gay Studies. 7(4), 621636. DOI:10.1215/10642684-7-4-621

- Butler, J. 2009. Krigets Ramar : När är livet sörjbart? Hägersten: Tankekraft.

- Dalgaard, M. 2016. Politikere om kønsopdelt svømmehal: "Grotesk" og "total fiasko". Politiken [Online]. [Lokaliserat 3. juli 2017]. Tillgänglig på: http://politiken.dk/indland/politik/art5620720 /Politikere-om-k\%C3\%B8nsopdelt-

sv\%C3\%B8mmehal-\%C2\%BBGrotesk\%C2\%AB-ograquototal-fiaskolaquo

- Danbolt, M. 2017. Retro Racism: Colonial Ignorance and Racialized Affective Consumption in Danish Public Culture. Nordic Journal of Migration Research. 7(2), 105-113. DOI:10.1515/njmr-2017-0013

- Dreyer, P. 2016a. Kvinfo: "Det er helt forkert vej at gå”. Berlinske [Online]. [Lokaliserat 3. Juli 2017]. Tillgängligt på: https://www.b.dk/nationalt/kvinfo-det-er-den-helt-forkerte-vej-at-gaa - Dreyer P. 2016b. Kendt debattør langer ud efter 
svømmehal: "Det er meget, meget misforstået hensyn og tolerance". Berlinske [Online]. [Lokaliserat 3. Juli 2017]. Tillgängligt på:

https://www.b.dk/nationalt/kendt-debattoerlanger-ud-efter-svoemmehal-det-er-meget-megetmisforstaaet-hensyn

- Dreyer, P. 2016c. Borgmester raser over svømmehaller: Slører vinduerne og forbyder drenge adgang for muslimske pigers skyld. BT [Online]. [Lokaliserat 3. Juli 2017]. Tillgängligt på: https://www.bt.dk/danmark/borgmester-raser-oversvoemmehaller-sloerer-vinduerne-og-forbyderdrenge-adgang-fo

. Dreyer, P. og Ejsing J. 2016. Nydanske piger indtager svømmehallen - hvis den er fri for drenge. Berlinske [Online]. [Lokaliserat 3. Juli 2017]. Tillgänglig på: https://www.b.dk/nationalt/nydanske-piger-indtager-svoemmehallen-hvis-den-er-frifor-drenge

- Holck, L. and Muhr, S. L. 2017. Unequal solidarity? Towards a norm-critical approach to welfare logics. Scandinavian Journal of Management. 33(1), 1-11. DOI:10.1016/j.scaman.2016.11.001 - de los Reyes, P. och Martinsson L. 2005. Olikhetens paradigm - och några följdfrågor. I: de los Reyes, P. och Martinsson, L. red. Olikhetens Paradigm-intresektionella perspektiv på ojämlikhetsskapande. Lund: Studentlitteratur.

- de los Reyes, P. 2005. Historia, tillväxt och arbete i det moderna paradigmet. I: de los Reyes, P. och Martinsson, L. red. Olikhetens Paradigm- intresektionella perspektiv på ojämlikhetsskapande. Lund: Studentlitteratur.

- Eduards, M. 2007. Kroppspolitik: om Moders Svea och andra kvinnor, Stockholm: Atlas Akademi.

- Eide, E. och Simonsen, A. 2008. Verden skapes hjemmfra. Oslo: Unipub.

. Ejsning, J. 2016. Trods kritik: Kønsopdelt svømmning fortsætter i København. Berlinske [Online]. [Lokaliserat 3. Juli 2017]. Tillgängligt på: https://www.b.dk/nationalt/trods-kritik-koensopdelt-svoemning-fortsaetter-i-koebenhavn - Fahlgren, S., Johansson, A. and Mulinari, D. 2011. Introduction: Challenging Normalization Processes in a Neoliberal Welfare State. In: Fahlgren S. Johansson, A. and Mulinari, D. eds. Normalization And "Outsiderhood" Feminist Readings of a Neoliberal Welfare State. Bentham Science Publisher e-books.

DOI:10.2174/97816080527901110101

. Gottschalck, A. 2016. Forsker: "Kønsopdelt svømmning avler fjendtlighed" Berlinske. [Online]. [Lokaliserat 3. Juli 2017]. Tillgängligt på: https://www.b.dk/nationalt/forsker-koensopdeltsvoemning-avler-fjendtlighed
. Hervik, 2015. Race, "race", racialisering, racisme og nyracisme. Dansk Sociologi. 26(1), 29-50.

DOI:10.22439/dansoc.v26il.4991

- Johansen, L. 2016. Byrådsflertal afliver kønsopdelt svømmeundervisning. Jyllands-Posten. Aarhus. [Online]. [Lokaliserat 3. Juli 2017]. Tillgängligt på: http://jyllands-posten.dk/aarhus/ politik/ECE9104763/byraadsflertal-afliver-koensopdelt-svoemmeundervisning/

- Justitsministeriet. 2018. Forslag til lov om andring af straffeloven (tildakningsforbud). København: Justitsministeriet.

- Keskinen, S. 2013. Antifeminism and white identity politics: political antagonisms in radical rightwing populist and anti-immigration rhetoric in Finland. Nordic Journal of Migration Research. 3(4), 225-232. DOI:10.2478/njmr-2013-0015 - Keskinen, S., Touri, S., Irni, S. och Mulinari, D. eds. 2009. Complying with colonialism. Gender, race and ethnicity in the Nordic region. Burlington: Ashgate Publishing Company.

- Koefod, J. 2005. Holddeling: Når der gøres maskulinitet og hvidhed. Kvinder, Køn es Forskning. 14(3), 42-52. DOI:10.7146/kkf.v0i3.28114 - Lorde, A. 2007. Sister Outsider: Essays \& Speeches by Audre Lorde. Berkeley: Crossing Press.

- Mohammad, S. 2015. Skilda badtider bevisar islamisters makt. SVT Nyheter- Opinion. [Online]. [Lokaliserat 30. augusti 2017]. Tillgänglig på: https://www.svt.se/opinion/article3146674.svt - Mohanty, C.T. 1984. Under Western Eyes: Feminist Scholarship and Colonial Discourses. Boundary 2. 12(3), 333-358. DOI:10.2307/1395054 - Mulinari, D. 2016. Gender equality, anti-feminism and Sweden Democrats. In: Martinsson, L., Griffin, G. and Nygren, K.G. eds. Challenging the myth of gender equality in Sweden. London: Policy Press.

- Mulinari, D. och Nergaard, A. 2010. Sverigedemokraterna och det teoretiska fältet. I: Deland, M., Hertzberg, F. och Hvitfeldt, T. red. Det vita fültet. Uppsala: Swedish Science Press.

- Myong, L. and Bissenbakker, M. 2014. Love without borders? White transraciality in Danish migration activism. Cultural Studies. 30(1), 129146. DOI: 10.1080/09502386.2014.974643 - Nielsen, H.P. 2012. Monopol på Ligestilling? Etniske minoritetskvinder om 'dansk' ligestilling. Kvinder, Køn \& Forskning. 21(4), 19-28. DOI:10.7146/kkf.v0i4.28149

- Nygren, K.G., Fahlgren, S., and Johansson, A. 2015. (Re)assembling the 'normal' in neoliberal policy discourses: tracing gender regimes in the age of risk. Nordic Journal of Social Research. 6(0), 23-42. DOI:10.7577/njsr.2081 
. Palmberg, M. 2009. The Nordic colonial mind. I: Keskinen, S., Touri, S., Irni, S. och Mulinari, D. eds. Complying with colonialism. Gender, race and ethnicity in the Nordic region. Burlington: Ashgate Publishing Company, 35-50.

- Prashad, V. 2000. The Carma of Brown Folk.

Minnesota: University of Minnesota.

- Rasmussen, L. A. 2016. S: Kønsopdelte svømmehaller er et angreb på ligestillingen. Altinget.

[Online]. [Lokaliserat 3. Juli 2017]. Tillgänglig på: http://www.altinget.dk/artikel/s-koensopdelte-svoemmehaller-er-et-angreb-paa-ligestillingen

- Redder, H. 2016. Støjberg raser over kønsopdelt svømmeundervisning: Varsler "drastiske beslutninger" TV2 Nyheder. [Online]. [Lokaliserat 3. Juli 2017]. Tillgängligt på:

http://nyheder.tv2.dk/politik/2016-04-27-stoejberg-raser-over-koensopdelt-svoemmeundervisning-varsler-drastiske

- Rizau. 2016. Mette Frederiksen om kønsopdelt svømning: Et forskruet syn på køn. Berlinske [Online]. [Lokaliserat 3. Juli 2017]. Tillgängligt på: https://www.b.dk/politiko/mette-frederiksen-om-koensopdelt-svoemning-et-forskruet-synpaa-koen

. Ritzau. 2017. DGI-Formand: Misforstået opgør med kønsopdelt svømning. BT. [Online]. [Lokaliserat 3. Juli 2017]. Tillgängligt på:

https://www.bt.dk/politik/dgi-formand-misforstaaet-opgoer-med-koensopdelt-svoemning - Scott Wallach, J. 2010. Slöjans politik. Hägersten: Tankekraft.

- Scholten, P., Collett, E. and Petrovic, M. 2017. Mainstreaming migrant integration? A critical analysis of a new trend in integration governance. International Review of Administrative Sciences. 83(2), 284-302.

DOI:10.1177/0020852315612902

- Siim, B. 2000. Gender and citizenship-politics and agency in France, Britain and Denmark. Cambridge: Cambridge University Press.
. Spilker, K. and Lie, M. 2007. Gender and bioethics intertwined. European Journal of Women s Studies. 14(4), 327-340.

DOI:10.1177/1350506807081879

. Sæhl, M. 2017. Debat: Er kønsopdelt svømning kvindefrigørende eller undertrykkende? $D R$. [Online]. [Lokaliserat 3. Juli 2017]. Tillgänglig på: https://www.dr.dk/nyheder/indland/debater-koensopdelt-svoemning-kvindefrigoerende-eller-undertrykkende

- Søndergaard, D.M. 2004. Intersectionality A Nordic Approach. Conference on Feminist Perspectives on Intersectionality, Schæffergården.

. Towns, A. 2002. Paradoxes of (In)Equality. Something is Rotten in the Gender Equal State of Sweden. Cooperation and Conflict. 37(2), 157179. DOI:10.1177/0010836702037002975 . Young, M. 2005. On Female Body Experience. Oxford: Oxford University Press. - Yuval-Davis, N. 2000. Gender and nation. London: SAGE.

- Yuval-Davis, N. 2011. The Politics of Belonging intersectional contestations. London: SAGE. - van Dijk, T. 1993. Elite Discourse and Racism. Newbury Park: SAGE.

- Ventegodt Liisberg, M. 2016. Lad være med at forbyde muslimske kvinder at svømme uden mænd. Jyllands-Posten. [Online]. [Lokaliserat 3. Juli 2017]. Tillgängligt på: https://jyllands-posten.dk/debat/breve/ECE91 17847/lad-vaeremed-at-forbyde-muslimske-kvinder-at-svoemmeuden-maend/

- Weheliye, A.G. 2014. Habeas Viscus: Racializing Assemblages, Biopolitics, and Black Feminist Theories of the Human. Durham: Duke University Press.

. Ålund, A. 2005. Feminism, Multiculturalism, Essentialism. In: Yuval-Davis, N. and Werbner, P. eds. Women Citizenship and Difference. London: Zabaan, 147-162. 